\title{
Application of Umbilical Cord Blood Derived Stem Cells in Diseases of the Nervous System
}

Bhagelu R Achyut"\#, Nadimpalli Ravi S Varma# and Ali S Arbab#

${ }^{1}$ Tumor Angiogenesis Lab, Cancer Center, Georgia Regents University, Augusta, GA 30912, USA

${ }^{2}$ Cellular and Molecular Imaging Laboratory, Henry Ford Hospital, Detroit, MI 48202, USA

\begin{abstract}
Umbilical cord blood (UCB) derived multipotent stem cells are capable of giving rise hematopoietic, epithelial, endothelial and neural progenitor cells. Thus suggested to significantly improve graft-versus-host disease and represent the distinctive therapeutic option for several malignant and non-malignant diseases. Recent advances in strategies to isolate, expand and shorten the timing of UCB stem cells engraftment have tremendously improved the efficacy of transplantations.

Nervous system has limited regenerative potential in disease conditions such as cancer, neurodegeneration, stroke, and several neural injuries. This review focuses on application of UCB derived stem/progenitor cells in aforementioned pathological conditions. We have discussed the possible attempts to make use of UCB therapies to generate neural cells and tissues with developmental and functional similarities to neuronal cells. In addition, emerging applications of UCB derived AC133+ (CD133+) endothelial progenitor cells (EPCs) as imaging probe, regenerative agent, and gene delivery vehicle are mentioned that will further improve the understanding of use of UCB cells in therapeutic modalities. However, safe and effective protocols for cell transplantations are still required for therapeutic efficacy.
\end{abstract}

Keywords: Umbilical cord blood; Embryonic stem cells; HSCs; GVHD; MSCs

\section{Introduction}

Self-renewal and differential capacity make stem cells as potential tools for regeneration, restoration or replacement therapies in a variety of disease conditions [1]. Moreover, due to its plasticity and tropism to accumulate in different lesions, stem cells can be used as a tool to carry therapeutic gene for repair or regeneration of affected tissues. Depending of their sources, stem cells are broadly categorized into embryonic stem cells (ESCs) i.e. cells derived from the inner cell mass of the blastocyst, and adult stem cells i.e. cells isolated from the adult bone marrow, peripheral blood or from specific organs. Induced pluripotent stem cells are the third category, where somatic cells are induced to convert into pluripotent stem cells under certain condition and differentiate into a specific cell types [2,3]. Fourth category is known as umbilical cord blood (UCB) or tissue derived stem cells that are isolated from placental tissues after the birth of baby. It consists of both hematopoietic stem cells (HSCs) as well as mesenchymal stem cells (MSCs) in mononuclear fraction of UCB [1,4,5]. Moreover placental tissue (such as membrane and Wartan's jelly) can also be utilized to generate multipotent stem cells [6,7]. UCB stem cells are considered between ESCs and adult stem cells [8]. Subpopulations of UCB stem cells carry gene expression that are similar to that of ESCs and bone marrow derived stem cells $[9,10]$. UCB derived stem cells have several advantages over ESCs and stem cells derived from adult bone marrow. Such advantages are: the source of UBC is literally unlimited; lower risk of transmitting infections; immediate availability; greater tolerance of human leukocyte antigen (HLA) disparity and lower incidence of inducing severe graft-versus-host disease (GVHD) [11-14]. This is because UCB derived stem cells are immature and are enriched with regulatory T cells, a kind of immune cell that suppresses immune responses $[13,15,16]$.

In the present review article we have discussed the potential use of UBC derived stem cells in neuroprotection, use in preclinical and clinical setting for therapies of neurological disorders, and emerging application of UCB derived endothelial progenitor cells (EPCs) as regenerative and imaging agent, as well as gene therapy vehicle for several neurological disorders and malignancies (Figure 1).

\section{Umbilical Cord Blood and Tissue-Derived Stem Cells in Improving Neuroregenaration}

Nervous system has limited regenerative potential in disease conditions such as cancer, neurodegeneration, stroke, and several neural injuries. Stem cells derived from adult source as well as placental tissues have been in a spot light to utilize to generate tissues of the nervous system during disease conditions. Initial investigations were directed towards the use of tissue specific stem cells collected from fetal brain (such as neural stem or progenitor cells collected from sub ventricular zone (SVZ) tissues) [17,18]. ESCs derived neural progenitor cells have also been used along with neural progenitor cells derived from bone marrow or umbilical tissues $[19,20]$. However, due to unwanted effects and limited sources, investigators have looked for alternative unlimited sources. Due to its advance in tolerance and less GVHD, UCB derived stem cells are being attempted in different animal disease models of central nervous system as well as in clinical setting [21]. Neural capabilities of UCB have been investigated and the results potentiate its role as a promising therapeutic tool for regeneration in neurological diseases [22-25]. Purification and in vitro characterization of UCB cellular fraction have been performed to understand the neural

*Corresponding author: Ali S Arbab, Tumor Angiogenesis Lab, Cancer Center Georgia Regents University, 1410 Laney Walker Blvd, CN3141, Augusta, GA 30912, USA, Tel: 706-721-8909; Fax: 706-434-6406; E-mail: aarbab@gru.edu

Received April 22, 2014; Accepted May 05, 2014; Published May 07, 2014

Citation: Achyut BR, Nadimpalli Ravi SV, Arbab AS (2014) Application of Umbilical Cord Blood Derived Stem Cells in Diseases of the Nervous System. J Stem Cell Res Ther 4: 202. doi:10.4172/2157-7633.1000202

Copyright: (c) 2014 Achyut BR, et al. This is an open-access article distributed under the terms of the Creative Commons Attribution License, which permits unrestricted use, distribution, and reproduction in any medium, provided the original author and source are credited. 

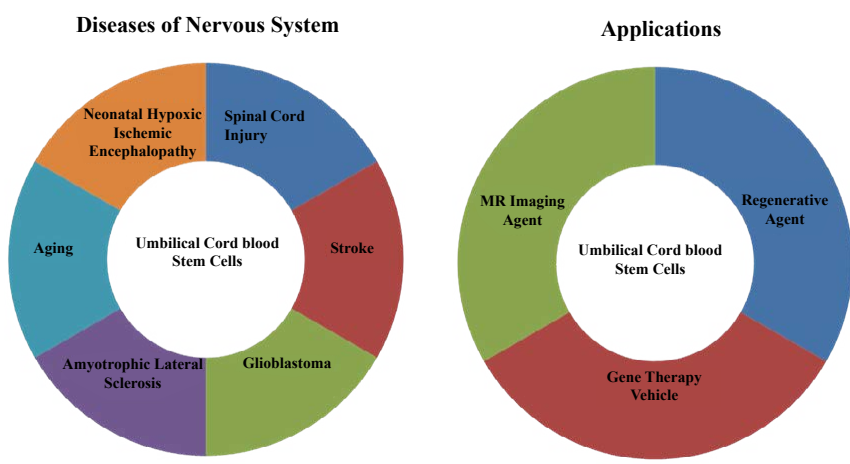

Figure 1: Therapeutic applications of human umbilical cord blood-derived stem cells in neurological disorders.

differentiation potential $[26,27]$, which have been characterized by the expression of mature neuronal marker proteins [23,24,28-32]. Studies have also investigated the population subset that represent neurogenic role of UCB cells. Study by Boltze et al. [33] suggests that UCB derived mononuclear cells; especially CD34+ cells provide the most prominent neuroprotective effect. In vitro studies showed that CD34+ subset preferentially reside in neural tissue. However, these mononuclear cells have lesser survival advantages in ischemic brain for longer periods without immunosuppression [33]. In addition, UCB stem cells regenerate functional neurons that have similarities to that of primary neurons, as shown by encouraging results from electrophysiological and molecular mechanistic studies [34,35]. Therefore, all of the above studies collectively suggest that UCB derived stem cells have great potential into clinical therapeutics of neurological diseases; however, CD34+ cell therapy from UCB may need immunosuppression.

On the other hand, investigators have isolated cells from UCB as well as from different placental tissues that can act as neural progenitor cells and helps in regeneration and restoration of neurons in stroke animals $[36,37]$. We have also used umbilical tissue derived cells, which improved vascularization, myelination and neurogenesis in an animal model of stroke $[36,38]$. These cells showed capacity to differentiate into neural progenitor cells.

\section{Preclinical and Clinical Advances in Neurological Disorders}

UCB stem cells have been investigated for safety and therapeutic potential on animal models of neurological diseases in order to use it for clinical applications. In humans, many neurodegenerative disorders are associated with hypoxia during birth or ageing, which are associated with the reduced neurogenesis and decline of proliferation of stem/progenitor cells [39-42]. In a first human trial, autologous UCB mononuclear cells were used in a case of cerebral palsy caused by hypoxiainduced brain damage. The results indicate that the administered UCB has contributed remarkable functional neuroregeneration [43]. Investigators also found that peripheral injection of mononuclear fraction of UCB revived the aged progenitor cells in the brain and stimulated endogenous stem cells to regenerate new cells [44]. Later, it was discovered that transplantation of mononuclear cells from UCB were incorporated in the damaged area of the brain into a rat model of prenatal brain damage [45]. These studies suggest that therapeutic potential of UCB stem cells via incorporation of cells into the injury site [45]. UCB stem cells have also been used in animal models of spinal cord injuries. The stem cells were injected along with brain derived neurotrophic factor (BDNF) into the spinal cord injury site in a rat model. After transplantation, the stem cells differentiated into neural cells at the injury site and showed positive effect on axonal regeneration [46]. In other study, transplanted UCB stem cells into rats subjected with cerebral artery occlusion to induce focal ischemia like pathology, resulted in improvement in animal functional condition [47]. These transplanted cells were detected in the affected cortex, sub-cortex and striatum of damaged brain expressing neuronal markers [48]. Above reports indicate that UCB stem cells are capable of incorporation into the damaged locations and neural differentiation in vivo, which is thought to help in the recovery process. Some other studies used mouse models and investigated the therapeutic potential of UCB stem cells in neurological diseases.

\section{Disease or Lesion Specific Use of UCB}

\section{Neuronal injury and stroke}

It is clear that UCB stem cells have a potential therapeutic impact on animal models of acute nervous system injuries as well as slowly progressive neurodegenerative diseases [22]. Thus, use of UCB stem cells in clinical applications for neural disorders is growing and will provide better option for cell therapy. In clinical trial, the potential of UCB autologous transplantation for newborns with hypoxic ischemic encephalopathy was tested, which provided promising tool to improve the clinical outcome in high-risk infants [49,50]. Perinatal hypoxic ischemic brain injury and stroke in the developing brain remain important causes of chronic neurologic morbidity. Promising data from preclinical studies suggest that transplantation of UCB stem cells may have therapeutic potential for neuroregeneration and improved functional behavior [51]. Umbilical cord MSCs (UC-MSCs) treatment improved the long-term functional outcomes of rats, increased mature oligodendrocyte counts, and decreased the number of reactive astrocytes and activated microglia quantities after hypoxia-induced periventricular white matter damage in the premature brain [52]. In mouse model, human UC-MSCs stimulated the injured brain and evoked trophic events, microglia/macrophage phenotypical switch, and glial scar inhibitory effects that remodeled the brain and lead to significant improvement of neurologic outcome [53]. In addition, potential use of UCB cells in neonatal brain injury has been exclusively reviewed by Varina et al. [54]. Stem cells are involved in the neurovascular repair of stroke [55] and possess a definitive role in neuronal rejuvenation following a cerebral injury [56]. For example, intravenous administration of human UCB-derived CD133+ EPCs reduces infarct volume in rat model of stroke [38]. EPCs transplantation significantly reduced apoptotic cell number, increased capillary density, stimulated neurogenesis, and reduced reactive astrogliosis at the site of injury in a rat model of transient middle cerebral artery occlusion (MCAO). These findings raise perspectives for the use of UCB cells as a well-characterized cell therapy product for optimal therapeutic outcome in stroke [57]. In addition, combination therapy has enhanced effect on stroke and recovery. The study by Cui et al, indicated that a combination of sub-therapeutic doses of Simvastatin and hUCB cells treatment increased Ang1/Tie2 and occludin expression in the ischemic brain, amplified endogenous angiogenesis and arteriogenesis, and enhanced vascular remodeling, thus contribute to functional outcome in stroke [58]. UCB-derived pan-hematopoietic CD45+ $\mathrm{CD} 11 \mathrm{~b}+$ cells improved the neurobehavioral deficits of traumatic brain injury upon i.v administration. The therapeutic effect was in a direct correlation to a reduction in the lesion volume [59]. In addition, combined therapy of UCB and granulocyte colony stimulating factor (G-CSF) displayed synergistic depletion of neuroinflammation, while 
enhancing endogenous neurogenesis, reducing hippocampal cell loss, long-lasting recovery of motor function in traumatic brain injury [60]. Considering the influence of the route of the administration of cells, intravenous administration of UCB cells was more effective than intrastriatal administration in producing functional benefit following stroke in rat models [61-63]. Local administration caused massive cell death compared to that of IV administration [64].

\section{Spinal cord injury}

Recently, transplantation of CD34+ human UCB cells during the acute phase promoted the functional recovery better than during the subacute phase after spinal cord injury (SCI) by raising blood vessel density, suggesting the possible clinical application for the treatment of spinal injury [65]. Purified MSCs from UBC were also used to treat SCI, which regenerated spinal cord, improved sensory perception and mobility [66].

\section{Glioblastoma}

Surprisingly, MSCs isolated from different sources have shown opposite effects. UCB derived MSCs inhibited glioblastoma (GBM) growth and resulted in apoptosis via tumor necrosis factor-related apoptosis-inducing ligand (TRAIL) expression, however, adipose tissue derived MSCs promoted GBM growth. Highly vascularized tumors were developed when adipose tissue derived MSCs and GBM were co-transplanted. UCB derived MSCs mediated delivery of secretable trimeric form of TRAIL (stTRAIL) was done via adenoviral transduction system, which showed more therapeutic efficacy characterized by significantly inhibited tumor growth and prolonged the survival of glioma-bearing mice compared with direct injection of adenovirus encoding the stTRAIL gene into a tumor mass [67]. Similar effect was seen when modified interleukin-12 (IL-12p40N220Q; IL$12 \mathrm{M})$ was used. Antitumor effects were associated with increased local IL-12M levels followed by interferon- $\gamma$ secretion, T-cell infiltration in intracranial gliomas and antiangiogenesis [68]. In addition, involvement of PDGF/PDGFR pathway has been implicated in human UCB induced apoptosis in GBM cells using both in vitro and in vivo studies [69]. These studies clearly demonstrate that UCB derived MScs have potential use as effective delivery vehicles for therapeutic genes in the treatment of intracranial glioma but the differences must be considered when choosing a stem cell source for safety in clinical application [70].

\section{Amyotrophic Lateral Sclerosis (ALS)}

Transplantation of UCB stem cells in mouse model of ALS delayed onset of symptoms and improved the health condition of the animals [47]. However, cell dosage and transplantation strategies need to be optimized in order to achieve the positive therapeutic impact [71]. Later it was found that multiple infusions of human UCB cells in a mouse model of ALS could benefit disease outcomes by protecting motor neurons from inflammatory effectors [72]. In addition, intraspinal injection of human UCB derived cells in G93A transgenic mouse model of ALS at early stages increased survival, which resulted in significant improvements in motor performance and astrogliosis in the spinal cord [73]. Recently, gene-cell therapy using UCB cells based on genetically modified mononuclear cells expressing vascular endothelial growth factor (VEGF) and reporter green fluorescent protein (EGFP) efficiently improved the parameters of motor and explorative activity, grip strength, and survival of SOD1 G93A transgenic mice having ALS [74].

\section{Multifaceted Therapeutic Applications of Human Umbilical Cord Blood-Derived AC133+ Endothelial Progenitor Cells}

Endothelial progenitor cells (EPCs) have been identified mainly in the mononuclear cell fraction of peripheral blood, leukapheresis products, and in UCB [75], which represent immense therapeutic potential roles such as regenerative agent, imaging probe and cell based carrier system for gene therapy. Janic et al. [76,77] have reported that cord blood $(\mathrm{CB})$-derived $\mathrm{AC} 133+(\mathrm{CD} 133+)$ cells has the ability to amplify the numbers of autologous EPCs by long term in vitro expansion while preserving their angiogenic potential, which is critically important for developing EPC based therapies. Previous studies including ours have shown the mechanism associated with the EPC's migration to damage area. EPCs have special affinity to migrate to damage area due to release stromal-cell derived factor (SDF-1) by tumor or ischemic lesions [78-81]. SDF-1 acts as a chemoattractant for EPCs migration due to abundant expression of CXCR4 receptors on cell membrane [81]. Moreover, EPCs were also shown to be attracted towards RANTES, which is an inflammatory cytokines [82]. It was found that the CYP4A/F-20-HETE system is expressed in EPCs derived from human UCB and can act as both an autocrine and a paracrine regulatory factor [83]. In this section, we intended to summarize the various novel studies, which were performed to show therapeutic potential of cord blood (CB)-derived AC133+ cells.

\section{Cord blood EPCs as a regenerative agent}

We have shown that stem/progenitor cells derived from human UCB improve structural and functional recovery in stroke models. We examined the effect of human UCB AC133+ EPCs on stroke development and resolution in a middle cerebral artery occlusion (MCAo) rat model using magnetic resonance imaging (MRI) to track in vivo the magnetically labeled EPCs. Accumulation of transplanted cells in stroke-affected hemispheres revealed that stroke volume decreased at a significantly higher rate and exerted a therapeutic effect on the extent of tissue damage, regeneration, and time course of stroke resolution [38]. Administration of human umbilical tissue derived cells significantly reduced ventricular volume and improved cerebral blood flow, which is histologically evidenced by enhanced expression of vWF and synaptophysin [36]. These studies indicate that UCB derived EPCs or tissue derived cells possess tremendous regenerative potential. However, application of UCB derived EPCs could be used extensively for other neurodegenerative disease if exploited correctly.

\section{Cord blood EPCs as a MR imaging probe}

A major challenge in the development of cell-based therapies for glioma or stroke is to deliver optimal number of cells (therapeutic dose) to the site of lesions. In addition, cord blood-derived EPCs has potential use as a therapeutic and imaging probe [84]. Authors report that new technique with short incubation time using $100 \mu \mathrm{g} / \mathrm{ml}$ of Ferumoxides and $3 \mu \mathrm{g} / \mathrm{ml}$ of Protamine sulfate is effective in labeling cells for cellular MRI [85]. They showed that labeling with ferumoxides-protamine sulfate complexes does not inhibit function or differentiation capacity of labeled cells [86]. Study by Varma et al. [87] evaluated the dynamic biodistribution of systemically injected labeled human UCB derived EPCs and cytotoxic T-cells (CTLs)] in rat glioma model, which was monitored by In-111 oxine based SPECT imaging. Magnetically labeled cord blood EPCs can be in vitro expanded and cryopreserved for future use as MRI probes for monitoring the migration and incorporation to the sites of neovascularization in an orthotopic glioma rat model [77]. 
Since, molecular and cellular imaging are essential in determination of bioavailability and efficacy of various drugs and targeting agents, exogenously labeled UCB cells can be used to determine the biodistribution of cells and therapeutic effects of UCB in brain lesions by MRI and UCB cells can be used as imaging probes.

\section{Cord blood EPCs based gene therapies}

For gene therapy, UCB EPC cells can be attractive as vehicles to deliver therapeutic molecules to the brain tumor area. EPCs possessed unique property to migrate to pathological lesions and showed active migration and incorporation into neovasculatures of glioma or in lesions when administered locally or systemically [87-89]. Tumor invasive properties of EPCs allow its possibility to use them as gene delivery vehicles to tumors [87-89]. EPCs based gene delivery offers several advantages over traditional gene therapy based on vectors or virus due to EPCs' ability to cross tumor blood brain barrier (TBBB) and also their extended homing properties at the disease site $[90,91]$. Vascular endothelial growth factor (VEGF) gene delivery through EPCs enhances the proliferation and migration of human aortic endothelial cells following ultrasonic microbubble transfection (UMT) [92]. Similar strategies can be used to deliver VEGF to stroke sites by using transgenic EPCs.

In cell based gene therapies, high level of therapeutic gene expression is important to get the desired effect at tumor/disease site. The transgene expression in EPCs depends on transduction process including promoter activity. Therefore, it is important to know promoter systems that can generate robust foreign gene expression in EPCs. We have evaluated and compared the ability of different commercially available promoters to drive the expression of transgenes in EPCs [89]. Strength of human cytomegalovirus (CMV) promoter, Simian virus 40 (SV40) promoter, mammalian Ubiquitin C (UBC) promoter and cellular polypeptide chain elongation factor 1 alpha (EF1) promoter was tested. We found that EF1 and CMV promoters are ideal for high level expression of transgene [89]. Recently, we have determine the migration and accumulation of genetically altered EPCs where UCB derived EPCs transduced to carry human sodium iodide symporter (hNIS) gene and injected into glioma bearing rats and we observed their migration to tumor site and functional expression of transgenes [91]. These experiments clearly highlight the capability of EPCs as gene delivery vehicles. Thus, cell based gene therapy is becoming an increasingly popular as alternative therapy for cancer and to accurately track these therapeutic cells has been critical for their success in clinical practice.

\section{Limitations and Future Directions}

Currently, UCB stem cells are latest and preferred tool over other types of pluripotent hematopoietic and mesenchymal stem cells for transplantation in animal- and patient- based studies [15]. It is clear that UCB derived cells have profound neurogenic potential. However, their regenerative property needs to be exploited in more efficient ways to treat neurological diseases. One of main hurdles in this direction is the limited availability of UCB in research uses. Therefore, major challenges are to expand or pool the available amount of UCB cells. Alternatively, other methods need to explore to boost the supply without losing its efficiency [15]. Thus, safe and effective protocols are required to establish for research and clinical use. Studies involving manipulation of UCB derived cells or subsets and mechanistic studies to validate the effect of transplantations are completely lacking. In addition, more awareness is required in basic science and clinical communities to collaborate and understand UCB's efficient use to combat the disease burden. Our laboratory has established the exploitation of one under-recognized subset (AC133+ EPCs) within mononuclear fraction of UCB cells in various applications.

\section{Acknowledgement}

Supported by the National Institutes of Health $(\mathrm{NIH})$ grants R01CA160216 and R01CA172048

\section{References}

1. Kogler G, Sensken S, Airey JA, Trapp T, Muschen M, et al. (2004) A new human somatic stem cell from placental cord blood with intrinsic pluripotent differentiation potential. J Exp Med 200(2): 123-135.[PubMed]

2. Jung Y, Bauer G, Nolta JA (2012) Concise review: Induced pluripotent stem cell-derived mesenchymal stem cells: progress toward safe clinical products. Stem Cells 30(1): 42-47.[PubMed]

3. Alvarez CV, Garcia-Lavandeira M, Garcia-Rendueles ME, Diaz-Rodriguez E, Garcia-Rendueles AR, et al. (2012) Defining stem cell types: understanding the therapeutic potential of ESCs, ASCs, and iPS cells. J Mol Endocrinol 49(2): R89-111.[PubMed]

4. Lim JY, Park SI, Oh JH, Kim SM, Jeong CH, et al. (2008) Brain-derived neurotrophic factor stimulates the neural differentiation of human umbilical cord blood-derived mesenchymal stem cells and survival of differentiated cells through MAPK/ERK and PI3K/Akt-dependent signaling pathways. J Neurosci Res 86(10): 2168-2178.[PubMed]

5. Divya MS, Roshin GE, Divya TS, Rasheed VA, Santhoshkumar TR, et al (2012) Umbilical cord blood-derived mesenchymal stem cells consist of a unique population of progenitors co-expressing mesenchymal stem cell and neuronal markers capable of instantaneous neuronal differentiation. Stem Cell Res Ther 3(6): 57.[PubMed]

6. Kim DW, Staples M, Shinozuka K, Pantcheva P, Kang SD, et al. (2013) Wharton ss Jelly-Derived Mesenchymal Stem Cells: Phenotypic Characterization and Optimizing Their Therapeutic Potential for Clinical Applications. Int J Mol Sci 14(6): 11692-11712.[PubMed]

7. Saeidi M, Masoud A, Shakiba Y, Hadjati J, Mohyeddin Bonab M, et al. (2013) Immunomodulatory effects of human umbilical cord Whartonıs jelly-derived mesenchymal stem cells on differentiation, maturation and endocytosis of monocyte-derived dendritic cells. Iran J Allergy Asthma Immunol 12(1): 37-49. [PubMed]

8. McGuckin CP, Forraz N, Baradez MO, Navran S, Zhao J, et al. (2005) Production of stem cells with embryonic characteristics from human umbilical cord blood. Cell Prolif 38(4): 245-255.[PubMed]

9. Wagner W, Wein F, Seckinger A, Frankhauser M, Wirkner U, et al. (2005) Comparative characteristics of mesenchymal stem cells from human bone marrow, adipose tissue, and umbilical cord blood. Exp Hematol 33(11): 1402 1416.[PubMed]

10. Efroni S, Duttagupta R, Cheng J, Dehghani H, Hoeppner DJ, et al. (2008) Global transcription in pluripotent embryonic stem cells. Cell Stem Cell 2(5): 437-447.[PubMed]

11. Zhong XY, Zhang B, Asadollahi R, Low SH, Holzgreve W (2010) Umbilical cord blood stem cells: what to expect. Ann N Y Acad Sci 1205: 17-22.[PubMed]

12. van Heeckeren WJ, Fanning LR, Meyerson HJ, Fu P, Lazarus HM, et al. (2007) Influence of human leucocyte antigen disparity and graft lymphocytes on allogeneic engraftment and survival after umbilical cord blood transplant in adults. Br J Haematol 139(3): 464-474.[PubMed]

13. Parmar S, Liu X, Tung SS, Robinson SN, Rodriguez G, et al. (2014) Third-party umbilical cord blood-derived regulatory $T$ cells prevent xenogenic graft-versushost disease. Cytotherapy 16(1): 90-100.[PubMed]

14. Danby R, Rocha V (2014) Improving Engraftment and Immune Reconstitution in Umbilical Cord Blood Transplantation. Front Immunol 5: 68.[PubMed]

15. Moyer MW (2013) Cell banks: life blood. Nature 498(7455): S16.[PubMed]

16. Yang J, Fan H, Hao J, Ren Y, Chen L, et al. (2012) Amelioration of acute graftversus-host disease by adoptive transfer of ex vivo expanded human cord blood CD4+CD25+ forkhead box protein 3+ regulatory T cells is associated with the polarization of Treg/Th17 balance in a mouse model. Transfusion 52(6): 1333-1347.[PubMed]

17. Doetsch F, Caille I, Lim DA, Garcia-Verdugo JM, Alvarez-Buylla A (1999) 
Subventricular zone astrocytes are neural stem cells in the adult mammalian brain. Cell 97(6): 703-716.[PubMed]

18. Maslov AY, Barone TA, Plunkett RJ, Pruitt SC (2004) Neural stem cell detection, characterization, and age-related changes in the subventricular zone of mice. $J$ Neurosci 24(7): 1726-1733.[PubMed]

19. Sanchez-Ramos JR (2002) Neural cells derived from adult bone marrow and umbilical cord blood. J Neurosci Res 69(6): 880-893.[PubMed]

20. Weissman IL, Anderson DJ, Gage F (2001) Stem and progenitor cells: origins phenotypes, lineage commitments, and transdifferentiations. Annu Rev Cell Dev Biol 17: 387-403.[PubMed]

21. Dalous J, Larghero J, Baud O (2012) Transplantation of umbilical cord-derived mesenchymal stem cells as a novel strategy to protect the central nervous system: technical aspects, preclinical studies, and clinical perspectives. Pediatr Res 71(4 pt 2): 482-490.[PubMed]

22. Ali H, Bahbahani $\mathrm{H}$ (2010) Umbilical cord blood stem cells - potential therapeutic tool for neural injuries and disorders. Acta Neurobiol Exp (Wars) 70(3): 316 324.[PubMed]

23. Zychowicz M, Mehn D, Ruiz A, Frontczak-Baniewicz M, Rossi F, et al. (2012) Patterning of human cord blood-derived stem cells on single cell posts and lines: Implications for neural commitment. Acta Neurobiol Exp (Wars) 72(4) 325-336.[PubMed]

24. Ali H, Jurga M, Kurgonaite K, Forraz N, McGuckin C (2009) Defined serum-free culturing conditions for neural tissue engineering of human cord blood stem cells. Acta Neurobiol Exp (Wars) 69(1): 12-23.[PubMed]

25. Arien-Zakay H, Lecht S, Nagler A, Lazarovici P (2010) Human umbilica cord blood stem cells: rational for use as a neuroprotectant in ischemic brain disease. Int J Mol Sci 11(9): 3513-3528.[PubMed]

26. McGuckin CP, Forraz N (2008) Umbilical cord blood stem cells--an ethical source for regenerative medicine. Med Law 27(1): 147-165.[PubMed]

27. McGuckin CP, Forraz N (2008) Potential for access to embryonic-like cells from human umbilical cord blood. Cell Prolif 41 Suppl 1: 31-40.[PubMed]

28. Habich A, Jurga M, Markiewicz I, Lukomska B, Bany-Laszewicz U, et al. (2006) Early appearance of stem/progenitor cells with neural-like characteristics in human cord blood mononuclear fraction cultured in vitro. Exp Hematol 34(7): 914-925.[PubMed]

29. Jurga M, Lipkowski AW, Lukomska B, Buzanska L, Kurzepa K, et al. (2009) Generation of functional neural artificial tissue from human umbilical cord blood stem cells. Tissue Eng Part C Methods 15(3): 365-372.[PubMed]

30. Kang XQ, Zang WJ, Bao LJ, Li DL, Xu XL, et al. (2006) Differentiating characterization of human umbilical cord blood-derived mesenchymal stem cells in vitro. Cell Biol Int 30(7): 569-575.[PubMed]

31. Tio M, Tan KH, Lee W, Wang TT, Udolph G (2010) Roles of db-cAMP, IBMX and $\mathrm{RA}$ in aspects of neural differentiation of cord blood derived mesenchymal-like stem cells. PLoS One 5(2): e9398.[PubMed]

32. Wang TT, Tio M, Lee W, Beerheide W, Udolph G (2007) Neural differentiation of mesenchymal-like stem cells from cord blood is mediated by PKA. Biochem Biophys Res Commun 357(4): 1021-1027.[PubMed]

33. Boltze J, Reich DM, Hau S, Reymann KG, Strassburger M, et al. (2012) Assessment of neuroprotective effects of human umbilical cord blood mononuclear cell subpopulations in vitro and in vivo. Cell Transplant 21(4): 723-737.[PubMed]

34. Habich A, Szablowska-Gadomska I, Zayat V, Buzanska L, Domanska-Janik K (2013) Epigenetic and molecular signature of human umbilical cord bloodderived neural stem cell (HUCB-NSC) neuronal differentiation. Acta Neurobiol Exp (Wars) 73(1): 143-156.[PubMed]

35. Buzanska L, Jurga M, Domanska-Janik K (2006) Neuronal differentiation of human umbilical cord blood neural stem-like cell line. Neurodegener Dis 3(1-2): 19-26.[PubMed]

36. Jiang Q, Thiffault C, Kramer BC, Ding GL, Zhang L, et al. (2012) MRI detects brain reorganization after human umbilical tissue-derived cells (hUTC) treatment of stroke in rat. PLoS One 7(8): e42845.[PubMed]

37. Chopp M, Zhang ZG, Jiang Q (2007) Neurogenesis, angiogenesis, and MRI indices of functional recovery from stroke. Stroke 38(2 suppl): 827-831. [PubMed]
38. Iskander A, Knight RA, Zhang ZG, Ewing JR, Shankar A et al. (2013) Intravenous administration of human umbilical cord blood-derived AC133+ endothelial progenitor cells in rat stroke model reduces infarct volume: magnetic resonance imaging and histological findings. Stem Cells Transl Med 2(9): 703-714.[PubMed]

39. Bachstetter AD, Pabon MM, Cole MJ, Hudson CE, Sanberg PR, et al. (2008) Peripheral injection of human umbilical cord blood stimulates neurogenesis in the aged rat brain. BMC Neurosci 9: 22.[PubMed]

40. Yang Z, Covey MV, Bitel CL, Ni L, Jonakait GM, et al. (2007) Sustained neocortical neurogenesis after neonatal hypoxic/ischemic injury. Ann Neurol 61(3): 199-208.[PubMed]

41. Artegiani B, Calegari $F$ (2012) Age-related cognitive decline: can neural stem cells help us? Aging (Albany NY) 4(3): 176-186.[PubMed]

42. Wang $X$, Zhao $Y$, Wang $X$ (2014) Umbilical cord blood cells regulate the differentiation of endogenous neural stem cells in hypoxic ischemic neonata rats via the hedgehog signaling pathway. Brain Res 1560: 18-26.[PubMed]

43. Jensen A, Hamelmann E (2013) First autologous cell therapy of cerebral palsy caused by hypoxic-ischemic brain damage in a child after cardiac arrestindividual treatment with cord blood. Case Rep Transplant 2013: 951827 [PubMed]

44. Park DH, Borlongan CV, Willing AE, Eve DJ, Cruz LE, et al. (2009) Human umbilical cord blood cell grafts for brain ischemia. Cell Transplant 18(9): 985 998.[PubMed]

45. Meier C, Middelanis J, Wasielewski B, Neuhoff S, Roth-Haerer A, et al. (2006) Spastic paresis after perinatal brain damage in rats is reduced by human cord blood mononuclear cells. Pediatr Res 59(2): 244-249.[PubMed]

46. Rodrigues LP, Iglesias D, Nicola FC, Steffens D, Valentim L, et al. (2012) Transplantation of mononuclear cells from human umbilical cord blood promotes functional recovery after traumatic spinal cord injury in Wistar rats. Braz J Med Biol Res 45(1): 49-57.[PubMed].

47. Chen R, Ende N (2000) The potential for the use of mononuclear cells from human umbilical cord blood in the treatment of amyotrophic lateral sclerosis in SOD1 mice. J Med 31(1-2): 21-30.[PubMed]

48. Lu D, Sanberg PR, Mahmood A, Li Y, Wang L, et al. (2002) Intravenous administration of human umbilical cord blood reduces neurological deficit in the rat after traumatic brain injury. Cell Transplant 11(3): 275-281.[PubMed]

49. Gortner L, Felderhoff-Muser U, Monz D, Bieback K, Kluter H, et al. (2012 Regenerative therapies in neonatology: clinical perspectives. Klin Padiat 224(4): 233-240.[PubMed]

50. Wang F, Maeda N, Yasuhara T, Kameda M, Tsuru E, et al. (2012) The therapeutic potential of human umbilical cord blood transplantation for neonatal hypoxic-ischemic brain injury and ischemic stroke. Acta Med Okayama 66(6): 429-434.[PubMed]

51. Castillo-Melendez M, Yawno T, Jenkin G, Miller SL (2013) Stem cell therapy to protect and repair the developing brain: a review of mechanisms of action of cord blood and amnion epithelial derived cells. Front Neurosci 7: 194.[PubMed]

52. Zhu LH, Bai X, Zhang N, Wang SY, Li W, et al. (2014) Improvement of human umbilical cord mesenchymal stem cell transplantation on glial cell and behavioral function in a neonatal model of periventricular white matter damage. Brain Res 1563: 13-21.[PubMed]

53. Zanier ER, Montinaro M, Vigano M, Villa P, Fumagalli S, et al. (2011) Human umbilical cord blood mesenchymal stem cells protect mice brain after trauma. Crit Care Med 39(11): 2501-2510.[PubMed]

54. Verina T, Fatemi A, Johnston MV, Comi AM (2013) Pluripotent possibilities: human umbilical cord blood cell treatment after neonatal brain injury. Pediat Neurol 48(5): 346-354.[PubMed]

55. Shinozuka K, Dailey T, Tajiri N, Ishikawa H, Kim DW, et al. (2013) Stem Cells fo Neurovascular Repair in Stroke. J Stem Cell Res Ther 4(4): 12912.[PubMed]

56. Dailey T, Tajiri N, Kaneko Y, Borlongan CV (2013) Regeneration of neurona cells following cerebral injury. Front Neurol Neurosci 32: 54-61.[PubMed]

57. Moubarik C, Guillet B, Youssef B, Codaccioni JL, Piercecchi MD, et al. (2011) Transplanted late outgrowth endothelial progenitor cells as cell therapy product for stroke. Stem Cell Rev 7(1): 208-220.[PubMed]

58. Cui X, Chopp M, Zacharek A, Dai J, Zhang C, et al. (2012) Combination treatment of stroke with sub-therapeutic doses of Simvastatin and human 
umbilical cord blood cells enhances vascular remodeling and improves functional outcome. Neuroscience 227: 223-231.[PubMed]

59. Arien-Zakay H, Gincberg G, Nagler A, Cohen G, Liraz-Zaltsman S, et al. (2014) Neurotherapeutic Effect of Cord Blood Derived CD45+ Hematopoietic Cells in Mice after Traumatic Brain Injury. J Neurotrauma.[PubMed]

60. Acosta SA, Tajiri N, Shinozuka K, Ishikawa H, Sanberg PR, et al. (2014) Combination therapy of human umbilical cord blood cells and granulocyte colony stimulating factor reduces histopathological and motor impairments in an experimental model of chronic traumatic brain injury. PLoS One 9(3): e90953.[PubMed]

61. Karlupia N, Manley NC, Prasad K, Schafer R, Steinberg GK (2014) Intraarterial transplantation of human umbilical cord blood mononuclear cells is more efficacious and safer compared with umbilical cord mesenchymal stromal cells in a rodent stroke model. Stem Cell Res Ther 5(2): 45.[PubMed]

62. Willing AE, Lixian J, Milliken M, Poulos S, Zigova T, et al. (2003) Intravenous versus intrastriatal cord blood administration in a rodent model of stroke. $J$ Neurosci Res 73(3): 296-307.[PubMed]

63. Chen J, Sanberg PR, Li Y, Wang L, Lu M, et al. (2001) Intravenous administration of human umbilical cord blood reduces behavioral deficits after stroke in rats. Stroke 32(11): 2682-2688.[PubMed]

64. Pawelczyk E, Arbab AS, Chaudhry A, Balakumaran A, Robey PG, et al. (2008) In vitro model of bromodeoxyuridine or iron oxide nanoparticle uptake by activated macrophages from labeled stem cells: implications for cellular therapy. Stem Cells 26(5): 1366-1375.[PubMed]

65. Ning G, Tang L, Wu Q, Li Y, Zhang C, et al. (2013) Human umbilical cord blood stem cells for spinal cord injury: early transplantation results in better local angiogenesis. Regen Med 8(3): 271-281.[PubMed]

66. Kang KS, Kim SW, Oh YH, Yu JW, Kim KY, et al. (2005) A 37-year-old spinal cord-injured female patient, transplanted of multipotent stem cells from human UC blood, with improved sensory perception and mobility, both functionally and morphologically: a case study. Cytotherapy 7(4): 368-373.[PubMed]

67. Kim SM, Lim JY, Park SI, Jeong CH, Oh JH, et al. (2008) Gene therapy using TRAIL-secreting human umbilical cord blood-derived mesenchymal stem cells against intracranial glioma. Cancer Res 68(23): 9614-9623.[PubMed]

68. Ryu CH, Park SH, Park SA, Kim SM, Lim JY, et al. (2011) Gene therapy of intracranial glioma using interleukin 12-secreting human umbilical cord bloodderived mesenchymal stem cells. Hum Gene Ther 22(6): 733-743.[PubMed]

69. Gondi CS, Veeravalli KK, Gorantla B, Dinh DH, Fassett D, et al. (2010) Human umbilical cord blood stem cells show PDGF-D-dependent glioma cell tropism in vitro and in vivo. Neuro Oncol 12(5): 453-465.[PubMed]

70. Akimoto K, Kimura K, Nagano M, Takano S, Tosa Salazar G, et al. (2013) Umbilical cord blood-derived mesenchymal stem cells inhibit, but adipose tissue-derived mesenchymal stem cells promote, glioblastoma multiforme proliferation. Stem Cells Dev 22(9): 1370-1386.[PubMed]

71. Habisch HJ, Janowski M, Binder D, Kuzma-Kozakiewicz M, Widmann A, et al (2007) Intrathecal application of neuroectodermally converted stem cells into a mouse model of ALS: limited intraparenchymal migration and survival narrows therapeutic effects. J Neural Transm 114(11): 1395-1406.[PubMed]

72. Garbuzova-Davis S, Rodrigues MC, Mirtyl S, Turner S, Mitha S, et al. (2012) Multiple intravenous administrations of human umbilical cord blood cells benefit in a mouse model of ALS. PLoS One 7(2): e31254.[PubMed]

73. Knippenberg S, Thau N, Schwabe K, Dengler R, Schambach A, et al (2012) Intraspinal injection of human umbilical cord blood-derived cells is neuroprotective in a transgenic mouse model of amyotrophic lateral sclerosis. Neurodegener Dis 9(3): 107-120.[PubMed]

74. Mukhamedyarov MA, Rizvanov AA, Safiullov ZZ, Izmailov AA, Sharifullina GA et al. (2013) Analysis of the efficiency of gene-cell therapy in transgenic mice with amyotrophic lateral sclerosis phenotype. Bull Exp Biol Med 154(4): 558561.[PubMed]

75. Asahara T, Murohara T, Sullivan A, Silver M, van der Zee R, et al. (1997) Isolation of putative progenitor endothelial cells for angiogenesis. Science 275(5302): 964-967.[PubMed]

76. Janic B, Guo AM, Iskander AS, Varma NR, Scicli AG, et al. (2010) Human cord blood-derived AC133+ progenitor cells preserve endothelial progenitor characteristics after long term in vitro expansion. PLoS One 5(2): e9173. [PubMed]
77. Janic B, Jafari-Khouzani K, Babajani-Feremi A, Iskander AS, Varma NR, et al. (2012) MRI tracking of FePro labeled fresh and cryopreserved long term in vitro expanded human cord blood AC133+ endothelial progenitor cells in rat glioma. PLoS One 7(5): e37577.[PubMed]

78. Arbab AS, Janic B, Knight RA, Anderson SA, Pawelczyk E, et al. (2008) Detection of migration of locally implanted AC133+ stem cells by cellular magnetic resonance imaging with histological findings. FASEB J 22(9): 3234 3246.[PubMed]

79. Finney MR, Fanning LR, Joseph ME, Goldberg JL, Greco NJ, et al. (2010) Umbilical cord blood-selected CD133(+) cells exhibit vasculogenic functionality in vitro and in vivo. Cytotherapy 12(1): 67-78.[PubMed]

80. Kioi M, Vogel H, Schultz G, Hoffman RM, Harsh GR, et al. (2010) Inhibition of vasculogenesis, but not angiogenesis, prevents the recurrence of glioblastoma after irradiation in mice. J Clin Invest 120(3): 694-705.[PubMed]

81. Shichinohe H, Kuroda S, Yano S, Hida K, Iwasaki Y (2007) Role of SDF-1/ CXCR4 system in survival and migration of bone marrow stromal cells after transplantation into mice cerebral infarct. Brain Res 1183: 138-147.[PubMed]

82. Silverman MD, Haas CS, Rad AM, Arbab AS, Koch AE (2007) The role of vascular cell adhesion molecule 1 / very late activation antigen 4 in endothelial progenitor cell recruitment to rheumatoid arthritis synovium. Arthritis Rheum 56(6): 1817-1826.[PubMed]

83. Guo AM, Janic B, Sheng J, Falck JR, Roman RJ, et al. (2011) The cytochrome P450 4A/F-20-hydroxyeicosatetraenoic acid system: a regulator of endothelial precursor cells derived from human umbilical cord blood. J Pharmacol Exp Ther 338(2): 421-429.[PubMed]

84. Janic B, Arbab AS (2012) Cord blood endothelial progenitor cells as therapeutic and imaging probes. Imaging Med 4(4): 477-490.[PubMed]

85. Janic B, Rad AM, Jordan EK, Iskander AS, Ali MM, et al. (2009) Optimization and validation of FePro cell labeling method. PLoS One 4(6): e5873.[PubMed]

86. Arbab AS, Yocum GT, Rad AM, Khakoo AY, Fellowes V, et al. (2005) Labeling of cells with ferumoxides-protamine sulfate complexes does not inhibit function or differentiation capacity of hematopoietic or mesenchymal stem cells. NMR Biomed 18(8): 553-559.[PubMed]

87. Varma NR, Shankar A, Iskander A, Janic B, Borin TF, et al. (2013) Differential biodistribution of intravenously administered endothelial progenitor and cytotoxic T-cells in rat bearing orthotopic human glioma. BMC Med Imaging 13: 17.[PubMed]

88. Rad AM, Iskander AS, Janic B, Knight RA, Arbab AS, et al. (2009) AC133+ progenitor cells as gene delivery vehicle and cellular probe in subcutaneous tumor models: a preliminary study. BMC Biotechnol 9: 28.[PubMed]

89. Varma NR, Janic B, Ali MM, Iskander A, Arbab AS (2011) Lentiviral Based Gene Transduction and Promoter Studies in Human Hematopoietic Stem Cells (hHSCs). J Stem Cells Regen Med 7(1): 41-53.[PubMed]

90. Kaneko Y, Tajiri N, Shinozuka K, Glover LE, Weinbren NL, et al. (2012) Cell therapy for stroke: emphasis on optimizing safety and efficacy profile of endothelial progenitor cells. Curr Pharm Des 18(25): 3731-3734.[PubMed]

91. Varma NR, Janic B, Iskander AS, Shankar A, Bhuiyan MP, et al. (2012) Endothelial progenitor cells (EPCs) as gene carrier system for rat model of human glioma. PLoS One 7(1): e30310.[PubMed]

92. Su CH, Wu YJ, Chang CY, Tien TY, Tseng SW, et al. (2013) The increase of VEGF secretion from endothelial progenitor cells post ultrasonic VEGF gene delivery enhances the proliferation and migration of endothelial cells. Ultrasound Med Biol 39(1): 134-145.[PubMed] 